\title{
Generational Divide: A New Model to Measure and Prevent Youth Social and Economic Discrimination
}

\author{
Luciano Monti ${ }^{1}$ \\ ${ }^{1}$ Fondazione Bruno Visentini, Rome, Italia \\ Correspondence: Luciano Monti, Fondazione Bruno Visentini, Via di Villa Emiliani 14/16, 00197 Roma, Italia. \\ Tel: 39-685-22-5059. E-mail: lmonti@luiss.it \\ Received: June 28, 2017 \\ doi:10.5539/res.v9n3p151 \\ Accepted: July 14, $2017 \quad$ Online Published: August 16, 2017 \\ URL: http://doi.org/10.5539/res.v9n3p151
}

\begin{abstract}
Measures concerning intergenerational inequality generally refer to youth unemployment or youth household income and wealth. The common conclusion is that the generational gap is represented by negative trend of youth unemployment and NEETS. In this paper, I argue that this phenomenon is not the cause of intergenerational unfairness, but one of its effects.

The pioneering efforts to measure the intergenerational fairness through a set of multidimensional indicators are the starting point for deeper analysis. The purpose of this paper, however, is not only to measure unfairness, but to quantify the generational divide. The latter is defined as the intensity of material and immaterial barriers affecting a sound development of individuals.

The way to measure such a phenomenon is to use a new and comprehensive, synthetic index, applied to the Italian youth emergency and social discrimination. For this reason some new indicators are added to the previous models, such as credit crunch, the scar inferred to NEET (Not in Education, Employment or Training), digital divide and barriers to mobility.

The results of this pilot analysis in the selected country for the period 2004-2012 demonstrate a worsening of the generational divide over the last five years and these high negative trends are mainly due to housing costs, decreasing incomes and the pension burden. These results suggest the need for a deep and careful consideration on the real intergenerational sustainability of current European and development strategies and show a large discrimination towards the younger generations.
\end{abstract}

Keywords: youth, young unemployment, discrimination, generational divide, Neet

\section{Introduction}

Unfairness among generations is normally considered a key concept within theories of social justice (Rawls, 1971) and mainly deals with studies concerning obligations to future generations (Sikora \& Barry, 1978; Frischmann, 2005) or the break of social contract between generations (Laslett, 1992). It is also denounced by several organizations and movements such as AFG Alliance for future generations (UK) IF Foundation (UK), Impetus-The Private Equity Foundation (UK), Roosevelt Institute Campus Network (US), Pensa 2040 (IT) and Think 2040 in US (Roosevelt Institute Campus Network, 2011).

The multidimensional approach for the identification of well-being indicators already counts some empirical analysis, both in the economic, social and environmental fields, following the main taxonomy identified by the Organization for Economic Cooperation and Development (OECD).

The weakness of current analysis is caused by the extreme complexity of creating a set of indicators and the time consuming data collection, especially if you want to rely on an updated overview for empirical analysis (Fitoussi, 2013).

The framework for the measurement of the generational divide includes thoughts and reflections on the depletion of human capital (Freeman, 1979), the scarring effects of youth unemployment (Gorlich, Stepanok, \& Al-Hussami, 2013), increasing entry wage differential (Gosling, Machin, \& Meghir, 2000), decreasing of salaries for younger cohort (Beaudry \& Green, 2000) and the available stock of real productive assets (Osberg, 1997). 
A way to consider intergenerational fairness moves from studies on the impact of governmental spending policies for growth and healthcare on future generations. In other words, this approach tries to assess the fiscal burden that current generations are placing on future generations. The resulting models are known as generational accounting (Auerbach, Gokhale, \& Kotlikoff, 1991, 1995) and deal with deficit spending or, more recently, with the issuing of Pensioner Bonds and with the shifting risk to future generations (Calabrese, 2009). Generational accounting has been tested within the budget process examining the issues associated with the long-term sustainability in some countries such as Australia since 2002 (Commonwealth Government, 2002).

Another point of view considers the impact of taxation on generational transfer to the intergenerational wealth mobility (Gale \& Slemrod, 2001; Jappelli, Padula, \& Pica, 2011).

The role of young generations in the active democracy is also under broad discussion as well as the impact of demographic change in political participation processes (Tremmel et al., 2015).

The first efforts to define a set of indicators could be considered the synthetic index of intergenerational justice, developed to measure "intergenerational (in) justice" in societies. Four content areas are taken into consideration: the ecological footprint, child poverty, the general government debt per person aged 0-14 and welfare states' overall pro-elderly bias in spending (Vanhuysse, 2014).

According to this index, the USA, Japan, Italy and Greece are placed among the unfairest countries, while Estonia and all the Nordic European countries are at the top of the rank (Vanhuysse, 2013).

The conclusion could be that, without "reforming current policy patterns" the economic and productivity growth in the near future, "would most likely mean that a high degree of injustice will continue to be inflicted upon currently young and future citizens" (Vanhuysse, 2014).

A remarkable contribution to this matter comes from the UNICEF child well-being Index, composed by five domains such as material well-being, health and safety, education, behavior and risks and housing \& environment, and analyzed through 26 indicators (Unicef, 2013). Once again all northern European countries are at the top of the rank, while at the bottom rank are placed Greece, US, Lithuania, Latvia and Romania.

However, the first pioneering attempt to measure the specific intergenerational gap has been developed in the UK by the IF-Intergenerational Foundation (Leach \& Hanton, 2013, 2014, 2015) by the Commonwealth Youth Programme, a research coordinated by the Institute for Economics and Peace (The Commonwealth, 2013) and in Italy by ClubdiLatina with the Generational Divide Index (ClubdiLatina, 2015).

The adopted taxonomy of IF index, since 2016, tested also at European level (Intergenerational Foundation, 2016), is composed by nine content areas: Unemployment, Housing, Pensions, Government Debt, Participation in Democracy, Health, Income, Environmental Impact and Education. Some of the indicators compare younger people's living standards with the national average, some other indicators deal with the impact on future generations.

On the one hand, the aim of the first analysis is to verify how young people are disadvantaged when compared with the rest of society. On the other hand, the analysis on future generations deals with the impact of current government policies on the well-being of these new coming generations. The rise of each component directly and proportionally can influence the index.

IF Researchers excluded the effect of inflation by using Gross Domestic Product (GDP) deflator and the population growth by looking at numbers on a per head basis.

As marked by the authors of the 2014 Report (Leach \& Hanton, 2014): "A rising index puts the social contract between the generations at risk". According to the European Intergenerational Fairness Index 2016, Slovenia, Estonia, Lithuania and Austria are at the top of the rank, while Greece, Italy and Romania at the bottom (Intergenerational Foundation, 2016).

The Youth Development Index (YDI) develops five domain datasets such as Education (providing meals for a year of schooling, public spending in education as \% of GDP and Youth literacy); Health and Well-being (Youth mortality rate, Use of Cannabis, Teenage pregnancy rate, HIV rate, use of tobacco); Civic Participation (youth volunteering, youth solidarity); Political Participation (youth policies and representation, voter education, express political views) and Employment youth unemployment, youth employment ratio. The YDI index (from 0 to $1 \mathrm{pt}$ ) is currently applied to 170 countries. Australia and Canada are at the top of the world rankings; the Netherlands and Germany at the top of the European Union rankings. UK scores 0,77 (ranking sixth in EU28), while Italy scores 0,70 (ranking 21th in EU28). 
This latter research also points out some interesting internal correlation among indicators such as Education outcomes and life expectancy and external correlation such as Education and gender equality (The Commonwealth, 2013).

The main purpose, however, is not to compare countries' youth unfairness but to measure the generational divide, i.e., the relevance of material and immaterial barriers affecting the sound development of young individuals and the relevance of generational discrimination in the country.

The first arising question is how we can define human capital components although it is not so important to quantify the stock of human capital but instead the decreasing quality. In other words, the focus should be on the definition of human "abilities", i.e., the basic condition allowing individuals to dispose of their own capital.

For our scopes, these abilities could be summarized in three main components: knowledge, mobility and access to services. Thanks to a broad and open knowledge, individuals can acquire and exchange information; thanks to a better mobility it is possible to reduce the time to go to school or to work and consequently the commuting stress factors (Turcotte, 2008; Koslowsky et al., 1995; Lyons \& Chatterjee, 2007; Kuennen, 2012) and to better health (Hennessy, 2008) and productivity (Kluger, 1998). Thanks to access to financial and training services, it is possible to invest in an individual's own personal or professional project and vocation.

The outcoming consequence of this approach is the introduction of new areas in the proposed new taxonomy for the Generational Divide Index (from now simply GDI) composed by 12 domains and 27 indicators (ClubdiLatina, 2015). The new index instead of intergenerational fairness or generational gap focuses on generational divide. The economic and cultural divide between the wealthy baby boomer generation and the disillusionment of the generation that now faces the labour market (Monti, 2016).

As far as a better knowledge is concerned, the new set includes indicators such as digital infrastructure for customers, digital interaction with government at central and local levels and E-Gov Use (Monti, Pepe, \& Rizzuti, 2015). As far as mobility is concerned, the new proposed indicators are: time spent getting to school and time spent going to work. Finally, the area of credit could be measured by two indicators; the first one considers the general credit crunch generated by the current crisis; the second one is the major effects of the credit crunch on younger generations.

This dataset has been applied to the Italian case, considering the institutional sources and the availability of relevant historical data series. The new dataset comes from open and official sources. The data series goes back in time as much as possible to have a historical trend of the selected indicators. The same GDI dataset could be applied to other countries with minor changes if all the historical series are available.

In the following chapter there is a brief description of indicators and sources applied to define the GDI for the case study (Fondazione Bruno Visentini, 2017).

Then, the conduct of each indicator or sub indicator is taken into account at this stage. The pattern followed by the GDI is that increases in its values represent a worsening of the situation for young people, and so the generational divide widens. With regard to the indicators, for which the lower the value of the indicator, the less the perceived level of generation gap, all the ratios are inverted. For example if the indicator value is 200 the reverse is $50=[1 /(200 / 100)]^{*} 100$. This is done for three sub-indicators: 2C-House Building, 5C-Age of parliamentarians and 9A-Level of Spent on Education. Where an indicator contains two or more sub-indicators the un-weighted arithmetic average of the relevant fixed base indicator has been used. Therefore, the final GDI shows the change forward in time and backward in time taking the figure of 100 in the year 2004 as a starting base.

\section{Method}

\subsection{Unemployment}

The content area Unemployment deals with Youth Unemployment indicator and with NEET indicator. The resulting ratio of youth unemployment monitors the proportion of the unemployed aged 15-24 cohort divided by the Italian average of unemployment. An increase in the ratio shows a widening of the generation gap. All data comes from Eurostat and the unemployment rate is obtained as a percentage ratio of the population over 15 years old looking for employment. The labour force is given by the sum of people in employment and people seeking employment. The definition of a person seeking employment refers to the concept of actively seeking work, i.e., having performed at least one job-seeking action of a given type in the four weeks preceding the one to which the information gathered during the interview refers and being available to work in the two weeks that follow.

The indicator dealing with young people neither in employment nor in education and training (NEET) corresponds to the percentage of the population aged 20-34 who is neither employed nor involved in further 
education or training. The ratio expresses the percentage of NEET as a proportion of the total population aged 20-34, considered the most relevant for the test. An increase in the percentage shows a worsening of the situation. The definition of young within a specific age range may vary in accordance with the sociocultural changes in society (Gallo, 2012). Indeed, in many researches on the Italian situation, the category of young people is extended until 34 years old in order to accurately grasp the transition from youth to adulthood (Cavalli, 2002).

\subsection{Housing}

The content Area Housing regards House affordability, Housing costs and House buildings. The first indicator assesses if housing is deemed affordable to young people with a median income. A low ratio indicates a good degree of affordability. The ratio compares the median levels of income among those aged 16-24 to the average house price values. The Income data come from Eurostat and includes: all income from work, private income from investment and property, transfer between households and all social transfers received in cash. Disposable income calculated by Eurostat excludes: imputed rent (i.e., money that one saves on full market rent by living in one's own accommodation or in accommodation rented at a price lower than the market rent) and non-monetary income components, in particular value of goods produced for own consumption, social transfers in kind and non-cash employee income except company cars. The house price results from calculations based on data coming from Agenzia delle Entrate (Income Revenue Authority) and the residential property price index from ECB.

The second indicator assesses the proportion of disposable income, spent yearly on housing costs. A deduction of the housing costs from income, measures how much is left to individuals. As a result, the increase in the ratio shows a reduction of disposable income available to young people. The housing costs include expense for housing (rent, imputed rent, water and condominium expenditures, ordinary maintenance, extraordinary maintenance); fuel and energy (electricity, gas, central heating); furnishings, households equipment and services (furniture, furnishing articles, household textiles, cleaning products, household utensils, paper napkins and dishes and aluminum containers, laundry, domestic service, repair of furnishing and household equipment). The ratio expresses housing costs as a proportion of disposable income of those aged 16-24. The income data comes from Eurostat, while information on household expenditures comes from ISTAT. According to ISTAT standard requirement, a group of people living in the same house related or connected by marriage, kinship, affinity, adoption, guardianship or sentiment, is referred to as Household.

The third indicator shows the level of house building compared to the need for new homes. The ratio expresses the numbers of building permits as a proportion of the number of households. A decrease in numbers of building permits indicates a reduction in intergenerational fairness. This is taken into account when these data are introduced into the index.

Differently from other indicators, a decrease in the ratio indicates a widening of the generational gap; for this reason, it has to be adjusted.

The number of building permits issued is used to proxy the number of houses built. The ratio expresses the numbers of building permits as a proportion of the number of households. Information on the number of building permits issued every year comes from ISTAT. Information on the number of households in Italy comes from Eurostat. According to Eurostat, household means a person living alone or a group of people who live together in the same private dwelling and sharing expenditures, including the joint provision of the living essentials. EU-SILC implementing regulation number 1983/2003 on updated definitions, defines households in terms of sharing household expenses and (for non-permanent members) in terms of duration of stay and (for temporarily absent members) in terms of duration of absence.

\subsection{Pensions}

The content area Pensions takes into account two indicators: the State pension costs and the Unfunded Public Sector Pension Costs.

The State pension cost per working person is measured dividing the total cost of State pension by the numbers of the Italian employed.

Pension costs are covered through the taxes paid by the currently working people.

The ratio shows the cost borne by each worker. An increase in the ratio shows a widening of the generation gap. The State Pension Cost data come from CTS Itinerari Previdenziali, while the data on people in employment comes from Eurostat. 
According to Eurostat, employment data comes from the number of persons employed and the number of employees. The Community Labour Force Survey defines employment (in accordance with the International Labour Office) as follows: persons in employment are those, aged 15 years and over and living in private households, who during the reference week did any work for pay or profit for at least one hour, or were not working but had jobs from which they were temporarily absent. Family workers are also included. The European System of Accounts (ESA) defines employment as covering both employees and self-employed people, who are engaged in some productive activity that falls within the production boundary of the system.

Employees are all persons who, by agreement, work for another resident institutional unit and receive a remuneration. An employer-employee relationship exists when there is an agreement, either formal or informal, between an enterprise and a person, normally entered into voluntarily by both parties, whereby the person works for the enterprise in return for remuneration in cash or in kind. Self-employed persons include the following categories: unpaid family workers, outworkers and workers engaged in production undertaken entirely for their own final consumption or for their own formation, either individually or collectively (Eurostat, 2013).

The unfunded liability of the public sector pension cost represents the benefits paid out by the government that are not offset by contributions, values of assets, savings or investments. The ratio divides the total cost of the unfunded liabilities of pensions cost by the numbers of the Italian workforce. It shows the extent of the debt per worker with regard to pensions. An increase in the ratio shows a widening of the generation gap. The bigger the unfunded pension costs the wider the generation gap.

\subsection{Government Debt}

The content area Government Debt: the indicator is given by the general government gross debt (excluding the unfunded liability of pensions) divided by the numbers of total employed. The ratio shows the cost borne by each worker. An increase in the ratio shows a widening of the generation gap. The Government consolidated gross debt data (adjusted by using unfunded pension costs) come from Eurostat and the indicator is defined as consolidated general government gross debt at nominal (face) value, outstanding at the end of the year in the following categories of government liabilities: currency and deposits, debt securities and loans. The general government sector includes the following subsectors: central government, state government, local government and social security fund.

\subsection{Participation in Democracy}

The content area Participation in Democracy regards the following indicators: Political confidence, Voting and Age of parliamentarians. The first one assesses the level of confidence in political parties amongst young people compared to the Italian average. The ratio compares the percentage of those aged 15-34 who express confidence in political parties to the total percentage of Italians with the same characteristics. An increase in the ratio represents a worsening of the situation for young people. The data come from the Research Institute Ipsos.

The second (voting) indicator assesses the levels of young people that did not participate in political elections. The ratio compares the number of those aged 18-24 who did not vote in the political elections to the total number of people aged 18-24 having the right to vote. An increase in the ratio represents a worsening of the situation.

The number of people aged 18-24 having the right to vote is obtained by subtracting the number of those having the right to vote at the Senate (voting rights for elections to the Senate belongs to Italian over the age of 25) from the total number of people having the right to vote at the Chamber of Deputy. The same logic is applied to calculate the number of young people that voted and those who did not.

Finally, the Age of Parliamentarians is measured considering the proportion of parliamentarians (in the Italian Chamber of Deputy) under 39 and over 40 . This aspect affects the country life in general and the impact of democratic processes (Tremmel et al., 2015).

Differently from other indicators, an increase in the ratio narrows the generation gap and this is taken into account in the final index. The data derives from the Italian Chamber of Deputy website.

\subsection{Health}

The content area Health refers to the self-perceived health of young people and the hospital days of under 34 inpatients. The ratio of the first indicator shows people aged 16-29 with a bad and very bad self-perceived health status of the total cohort. An increase in the percentage represents a worsening of the situation for young people. The absolute values reported on the line graph are obtained considering those aged 16-29 years with a bad and very bad self-perceived health status on the total population aged from 16 to 29 . Information on the self-perceived health of young people comes from Eurostat surveys on how a person perceives his/her health in 
general using one of the answer categories very good/good/fair/bad/very bad. Individuals aged from 16 to 29 years old living in private households are considered as statistical units.

The second indicator assesses the hospital days of in-patients considered as bed-days for all causes of disease. The aim is to assess the usage of health service among younger people compared to adult people. The ratio is calculated dividing the percentage of those aged over 35 to the percentage of those aged under 34 . An increase implies a widening of the generation gap. All data come from Eurostat. In-patient is defined as a patient who is formally admitted (or "hospitalised") to an institution for treatment and/or care and stays for a minimum of one night or more than 24 hours in the hospital or other institution providing in-patient care.

\subsection{Income \& Wealth}

The content area Income \& Wealth takes into account two indicators: Income and Wealth. The income indicator compares the median income levels amongst young people aged 16-24 to the average of entire population (amongst those in employment). The ratio shows the relationship between median income of adults and median income of young people. An increase in the ratio shows a larger difference between young people and adult people median income. All data come from Eurostat and the disposable income includes: all income from work (employee wages and self-employment earning); private income from investment and property; transfers between households, all social transfers received in cash including old-age pensions. Some of the income components, Imputed rent, Interest paid on mortgage, employer's social insurance contributions are mandatory only since 2007. Since then, all countries have been supplying gross income information. The current definition of total household disposable income used for the calculation of EU-SILC based indicators excludes: imputed rent and non-monetary income components, in particular value of goods produced for own consumption, social transfers in kind and non-cash employee income except company cars.

The net household wealth represents the sum of the real assets (real estate, businesses and valuables) and financial assets (deposits, bonds, shares, etc.), less the financial liabilities (mortgages and other debts). The Wealth indicator compares the median wealth levels of young households (main income from family earner aged until 35) to the median households' wealth. Data come from the Survey on Household Income and Wealth conducted by the Bank of Italy. Wealth is considered in terms of real estate, financial assets and liabilities.

\subsection{Environment}

The content area Environment measures the environment impact and $\mathrm{CO} 2$ emissions. The first measure describes the environmental impact of Italian energy consumption. The graph shows the Italian greenhouse gas emissions, weighted by global potential warming (million tonnes carbon dioxide equivalent). For the purpose of this analysis, greenhouse gas emissions comprise carbon dioxide $(\mathrm{CO} 2)$, nitrous oxide $(\mathrm{N} 2 \mathrm{O})$ and methane $(\mathrm{CH} 4)$. An increase in the data shows a worsening of the situation. Fluorinated gasses (hydrofluorocarbons, perfluorocarbons, and sulfur hexafluoride), which are responsible for about $2 \%$ of the EU's greenhouse gas emissions, are not included in this analysis. The data related to the environmental impact come from OECD Statistics.

The $\mathrm{CO}_{2}$ in Atmosphere indicator describes the impact of climate change on the world. The value measures the $\mathrm{CO}_{2}$ emission, expressed as a mole fraction in dry air, micromol/mol abbreviated as ppm. An increase in the value represents a worsening of the situation. The data come from Mauna Loa Observatory, a premier atmospheric research facility that has been continuously monitoring and collecting data related to atmospheric change since 1950 .

\subsection{Education}

The content area Education is measured by the Level of government expenditure in Education and Numbers of early leavers. Early leavers from education and training, generally refer to people aged 18 to 24 who have accomplished/achieved no more than a lower secondary education and are not involved in further education or training; their number is expressed as a percentage of the total population aged 18 to 24 .

The indicator of level of expenditure describes general national government expenditure on education over a given time period. The ratio shows the Italian government expenditure as percentage of GDP (euro). Differently from other indicators, an increase in the ratio shows an improvement of the situation for young people. This is taken into account when the data are introduced into the final index. As far as the definition of general government expenditure is concerned, the definition reported in Commission Regulation 1500/2000 was taken into account. Gross Domestic Product refers to the nominal GDP, i.e., GDP at current prices.

The indicator of early leavers assesses the percentage of young people aged 18-24 who did not participate in higher education compared to early school leavers in EU-28 countries. The resulting ratio is calculated dividing 
the percentage of Italian early school leavers by the European ones. An increase in the ratio shows a worsening of the situation for Italian young people compared to European young people over a given time period. All data come from Eurostat.

\subsection{Credit}

The area of Credit is measured in terms of general credit crunch and compares the credit of young households with the rest of population.

The general indicator assesses the level of household debt in Italy. The resulting ratio is calculated dividing the percentage of Italian household debt (data from OECD database) and the percentage of European household debt (calculated as the unweighted average among the values of household debt in each European country). An increase in the ratio shows a worsening of the situation in Italy. According to OECD definition, "Household debt" is described as all liabilities that require payment or payments of interest or principal by household to the creditor at a date or dates in the future. Consequently, all debt instruments are liabilities, but some liabilities such as shares, equity and financial derivatives are not considered as debt. According to the 1993 System of National Accounts, OECD considers debt as the sum of the following liability categories, whenever available/applicable in the financial balance sheet of the households and non-profit institutions serving households sector, such as: currency and deposits; securities other than shares, except financial derivatives; loans; insurance technical reserves; and other accounts payable. For households, liabilities predominantly consist of loans, in particular mortgage loans for the purchase of houses (OECD, 2014).

Household debt is measured by the OECD as a percentage of Net Disposal Income (NDI). Thus, a reduction in the percentage can be attributed to improvements to income or to a reduction in debt, in particular consumer credit and mortgage loans. It is the most frequently reported measure on the indebtedness of households and intends to assess debt sustainability of the household sector. The Generation Credit Crunch assesses the availability of loans from the bank for those aged under 35. A Credit Crunch is the reduction in the general availability of loans or credit or a sudden tightening of the conditions required to obtain loans from the banks (Bankpedia, 2015). The resulting ratio is calculated dividing the proportion of loans taken out by those aged over 35 by the proportion of loans taken out by those aged under 35 . An increase in the ratio shows a widening of the generation gap.

Data referring to under 35 and over 35 people access to loans come from Mutui Online, the first mortgage broker in the Italian market and a landmark in the market of mortgages to retail consumers (Gruppo Mutui Online, 2015).

\subsection{Digital Divide \& Mobility}

The area Digital Divide \& Mobility refers to two main indicators: mobility, composed by two sub-indicators and digital divide, composed by three other more specific sub-indicators.

The first sub indicator (mobility to school) assesses the number of young people spending at least 30 minutes to go to school. The resulting ratio is calculated dividing the percentage of people aged 20 to 24 to those aged under 35 both spending at least 30 minutes to go to school. All the percentage values come from ISTAT database that every year carries out a Multipurpose survey on households: "Aspects of daily life". The sample survey "Aspects of daily life" is part of an integrated system of social surveys-The Multipurpose Surveys on Household-and collects fundamental information on individual and household daily life. Through questionnaires, the survey obtains information on citizens' habits and the problems they face in their everyday life.

Time spent to go to work ratio (second sub-indicator mobility at work) is calculated dividing the percentage of people aged 25 to 35 to the Italian population spending at least 30 minutes to go to work. All the percentage values come from the mentioned survey "Aspects of daily life" carried out by ISTAT.

The other main indicator, @PPR (Digital Private-Public Relations) assesses the relationship between economic growth and e-government, thanks to three sub-indicators: the use of e-government services, private-public interactions and digital infrastructures. The use of e-government services is composed by two sub-indicators: satisfaction and problems in the use of e-government websites. According to the level of satisfaction and problems a score is assigned: if the recorded value is lower than European average the score assigned is zero, if the value is equivalent to European average or higher the score assigned is 0.5 .

Digital infrastructures domain is made of three sub-indicators: LTE coverage; broadband subscription $>=30$ Mbps and use of internet (Monti, Pepe, \& Rizzuti, 2015). 
Concerning the use of government's online platform, according to available data, a score has been assigned in relation to satisfaction (A1) and problem levels (A2) compared to the EU 28 average (under average $=0$; equal or over average $=0.5$ ). The yearly sub-value is equal to $(\mathrm{A} 1+\mathrm{A} 2) / 2$. Interaction with citizens is autonomously considered in $\mathrm{B} 1$ as the number of connected people to public services $/ 100$.

Concerning broadband and connectivity three elements have been considered; Internet access (C3); since 2010 LTE $4^{\text {th }}$ generation coverage (C2); starting from 2011 high speed connection $(\mathrm{C} 1)$. Therefore, starting from 2010 the sub value is equal to $(\mathrm{C} 3+\mathrm{C} 2) / 2$. Since 2011 sub-value is equal to $(\mathrm{C} 1+\mathrm{C} 2+\mathrm{C} 3) / 3$.

The resulting ratio is calculated dividing the EU28@PPR by Italian@PPR value.

\subsection{Legality \& Transparency}

The last area Legality \& Transparency refers to the Corruption Perception Index (CPI) the most widely used indicator of corruption worldwide. It is a composite index developed by Transparency International that scores and ranks countries based on how corrupt a country's public sector is perceived to be. The CPI scores are in the range 0 to 100 (=lowest level of perceived corruption). The resulting ratio is calculated dividing the European CPI (as an un-weight average of all European members in each year) by the Italian CPI values. An increase in the ratio shows a worsening of the situation.

\section{Results}

The multiple and synthetic GDI shows a worsening of the youth divide in Italy starting with the current economic crisis (Figure 1a) and significant worsening during the further recession period starting from year 2010 (Figure 1b).

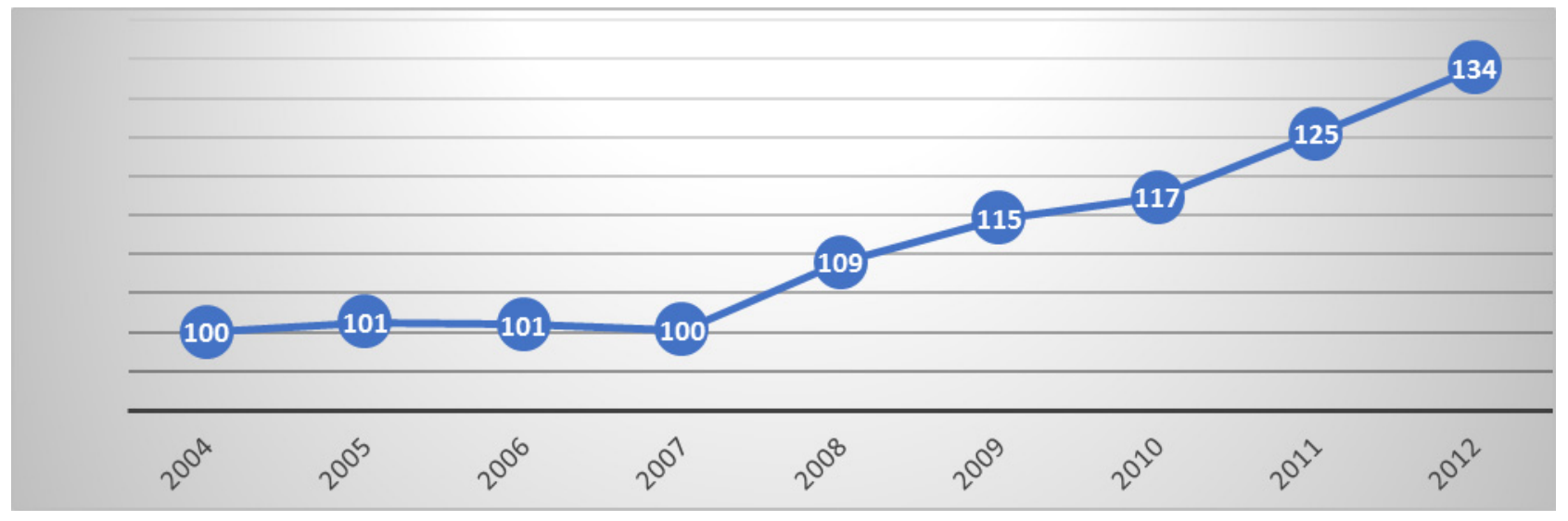

Figure 1a. Generational Divide Index for Italy 2004-2012 (2004=100)

Source: Monti, L. (Ed.). (2015). Most updated analysis in Marchetti, F., \& Monti, L. (Eds). (2017).

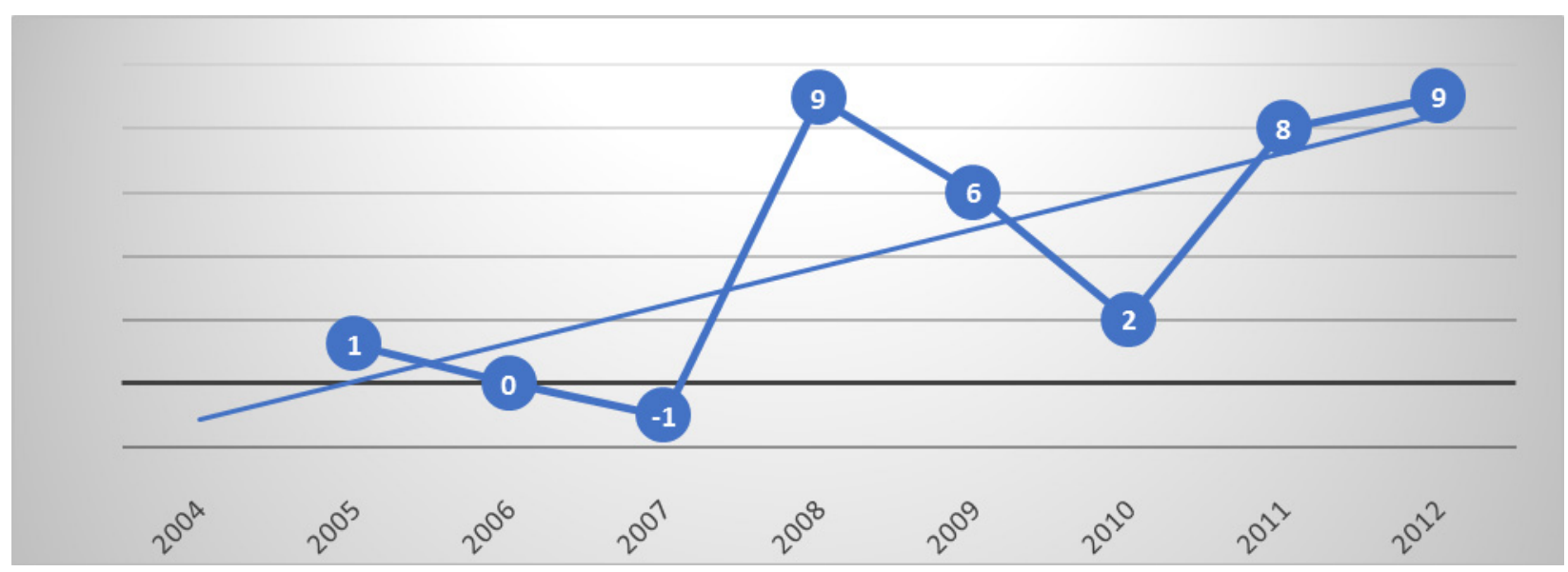

Figure 1b. Generational Divide Index Marginal growth and trend (\%) 
The least square method forecast methodology has been adopted to predict the trend of the GDI and identifies the value of the dependent variable Y (in this case the value of the GDI in 2013) through a simple linear equation such as:

$$
\mathrm{Y}=\mathrm{bx}+\mathrm{a}
$$

The parameters $b$ and $a$ are able to minimize the sum of squared residuals between the observed value and the hypothetical future value.

The linear equation mentioned above can be used to make a prediction of dependent variable $\mathrm{Y}$ value (the value of the GDI in 2013) in correspondence with X values not observed (years 2013, 2014, etc.), by replacing X with the values that will be necessary to predict the $\mathrm{Y}$. These values correspond to the independent variable $(\mathrm{X})$ and is conventionally considered the first year (2004) equal to zero, the second year (2005) equal to 1 and so on. Parameter $b$ and $a$ are calculated by those formulas

$$
\mathrm{a}=\bar{y}-\mathrm{b} \cdot \bar{x}
$$

$\bar{y}=$ the average of $\mathrm{y}($ GDI values $)=$ the average of $\mathrm{x}$ (years) $n$ : number of observations.

The results of 2013 have been adjusted considering the available annual dataset of some indicators. The forecast of democracy's indicator has been adjusted considering the exceptionality of the parliamentary age decrease registered in the last national election day and is therefore not a relevant trend. Total results are shown above in Figure 2a.

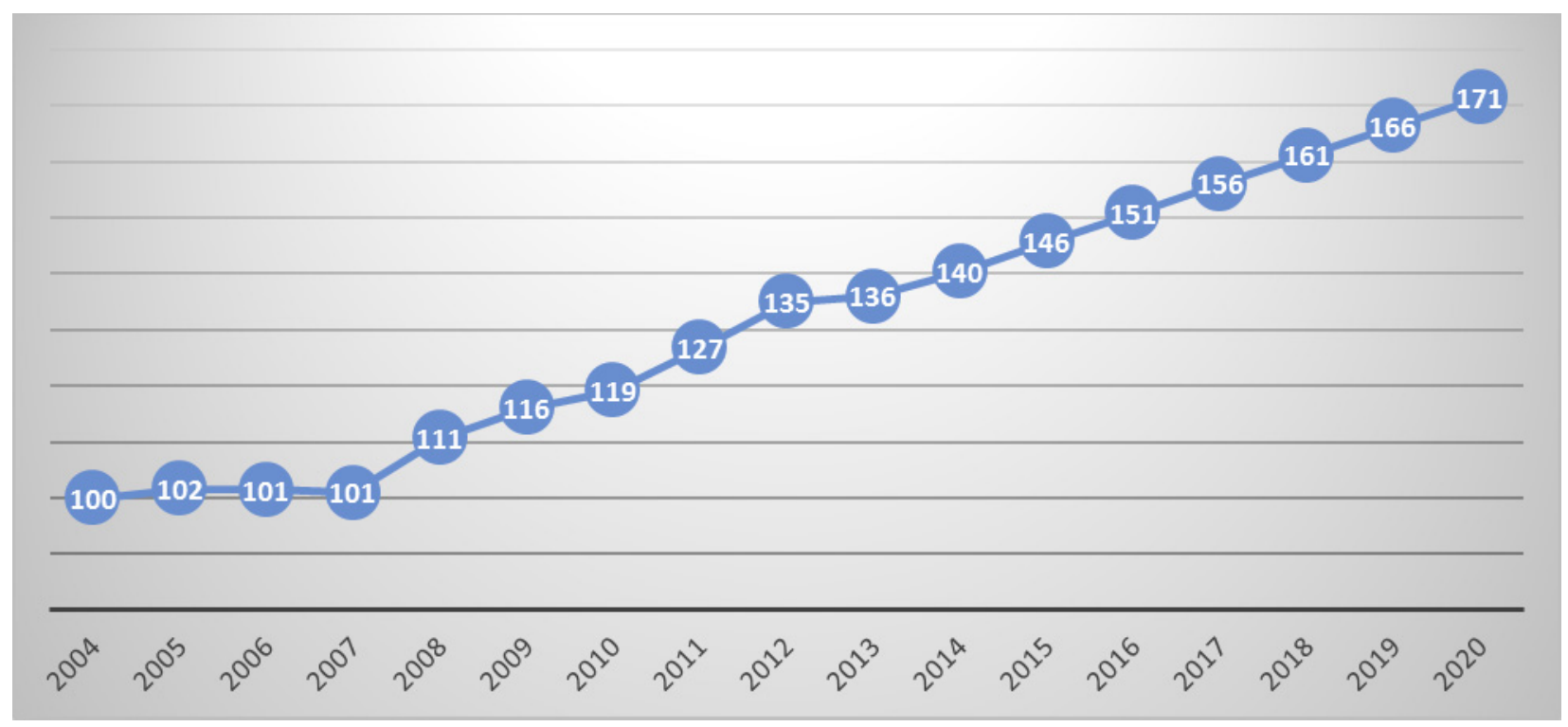

Figure 2a. Generational Divide Index forecast 2020

Source: Monti, L. (Ed.). (2015). Most updated analysis in Marchetti, F., \& Monti, L. (Eds). (2017).

The forecasted GDI Index for the period 2013-2014 and 2015-2020 could exceed 146 and 171 points respectively, which equates to more than $40 / 70 \%$ from the beginning of the current crisis. The forecast should be considered prudential, since no other negative factors have been considered such as a new recession phase, a new increase of the housing costs or extraordinary fiscal acts to recover the government debt or the actual welfare system. 


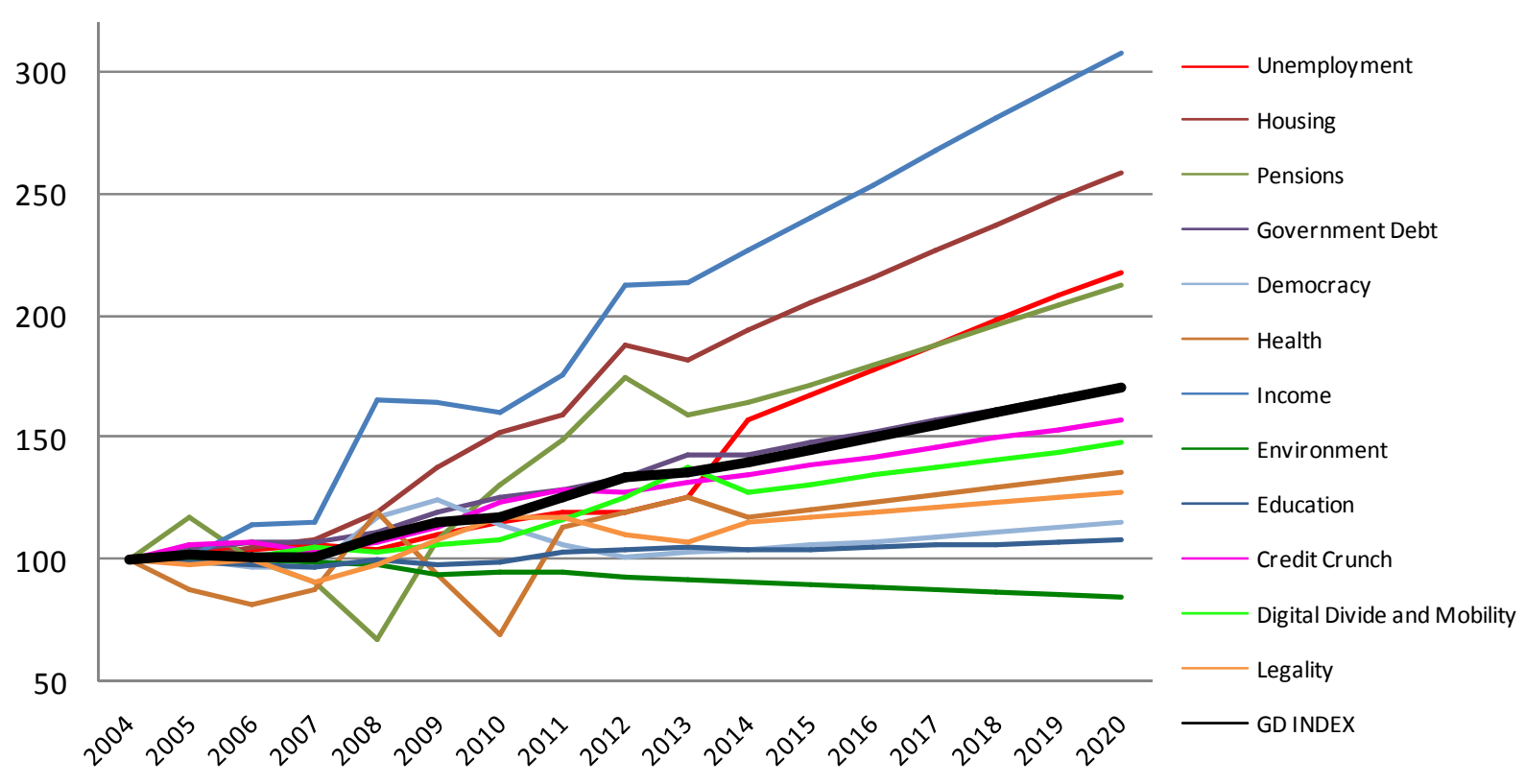

Figure 2b. GDI major impact factors forecast 2020

Source: Monti, L. (Ed.). (2015): 2030 forecast in Marchetti, F., \& Monti, L. (Eds). (2017).

It would be easy to state that the deterioration is simply due to a "structural" weakness and vulnerability of the younger generations, but this is not the case. This negative trend of youth unemployment and NEETs are not the cause of the actual intergenerational unfairness, but one of its effects.

Coming back to 2004-2012 GDI, if we consider the single content, as shown in Figure $2 \mathrm{~b}$ we realize that youth unemployment has a relevant correlation with the GDI index, although with a worsening trend.

Figure 3a shows only those indicators considered mainly responsible for the worsening of GDI: Income \& wealth Housing, Pensions.



Figure 3a. Areas of major actual worsening

Source: My elaboration on ClubdiLatina data. 
These are therefore the three area contents to be explored in order to define the real impact of the intergenerational divide. Also the forecast confirms this conclusion, adding Unemployment (Figure 3b).



Figure $3 b$. Areas of major forecasted worsening

Source: My elaboration on ClubdiLatina data.

\section{Discussion and Conclusion}

Since Housing, Income \& Wealth and Pensions have the greatest impact on intergenerational divide in the selected country, the focus in now on the single data and highlights indicators and sub-indicators trends. Every turning point, i.e., a relevant inversion of the ratios' trend, will be connected to the major reforms that occurred in the country in the last decades and to key events within the European integration process.

\subsection{Income \& Wealth}

Income \& wealth: Figure 4 compares the median annual income of Italian people with the median annual income of people 16-24 years old.



Figure 4. Median annual income (euro) of Italian (blue line) compared to the median annual income of those aged 16 to 24 (green line)

Source: Monti, L. (Ed.). (2015). 




Figure 5. Resulting ratio describing the difference among the median income level of the population and the median income of young people (median income of all divided by that of those aged 16-24)

Source: Monti, L. (Ed.). (2015).

Through an analysis of the 16-24 cohort annual revenue, the turning point is 2009. After a positive trend from this year, the curve is in stable decline except for an interruption in 2012 and a negative peak in $2013(-2.26 \%)$.

The long-term worsening situation of young income, however, could be registered since the beginning of the nineties and it is mainly the result of the introduction of a dual labor market opening a gap between old workers and new entrants (Rosolia \& Torrini, 2007).

Because of these amendments the youth situation became more flexible (Salvini \& Ferro, 2005) and less secure. This resulted in young workers having less guarantees and earning less than the older generations with the high style contracts, advantages and rights.

The financial and economic crisis together with the rising labor tax, incentivised companies to employ cheaper young workers with the mentioned new form of contracts with evident negatives consequences in terms of efficiency and professional competence (Cnel, 2013).

Dealing with wealth, the comparison is between annual median young households' wealth and the net family wealth as described in Figure 6.

\subsection{0}

160.000

140.000

120.000

100.000

80.000

60.000

40.000

20.000

0

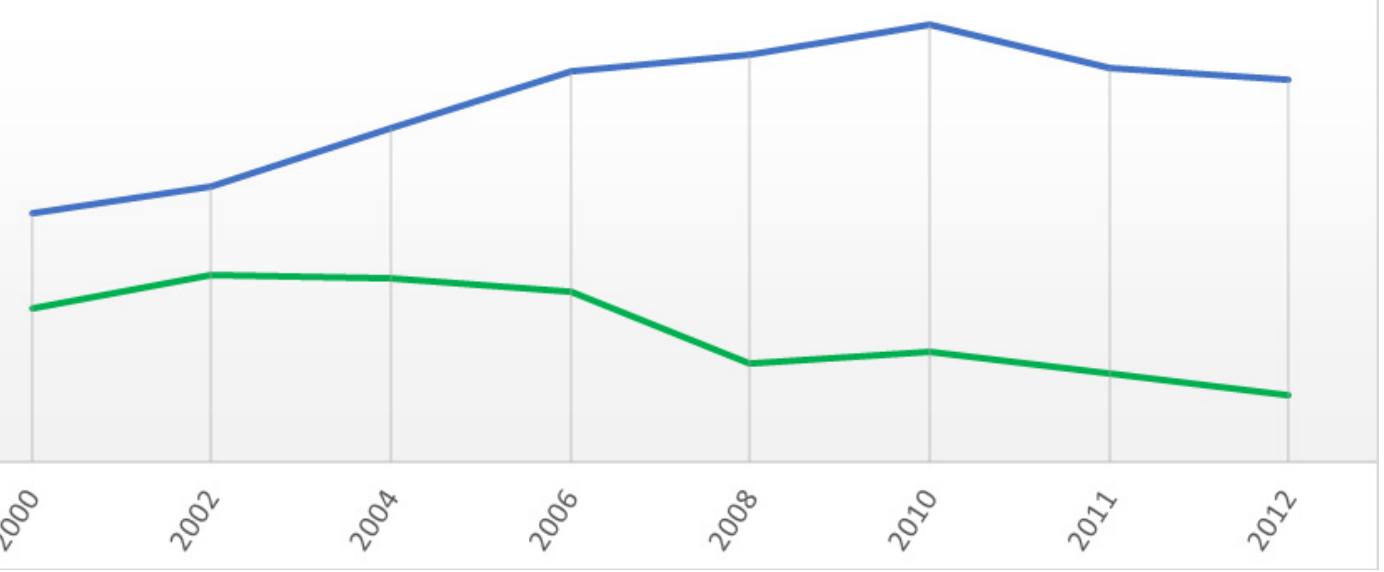

Figure 6. Median annual wealth (euro) of total Italian households (blue line) compared to the annual median young households wealth (green line)

Source: Monti, L. (Ed.). (2015). 


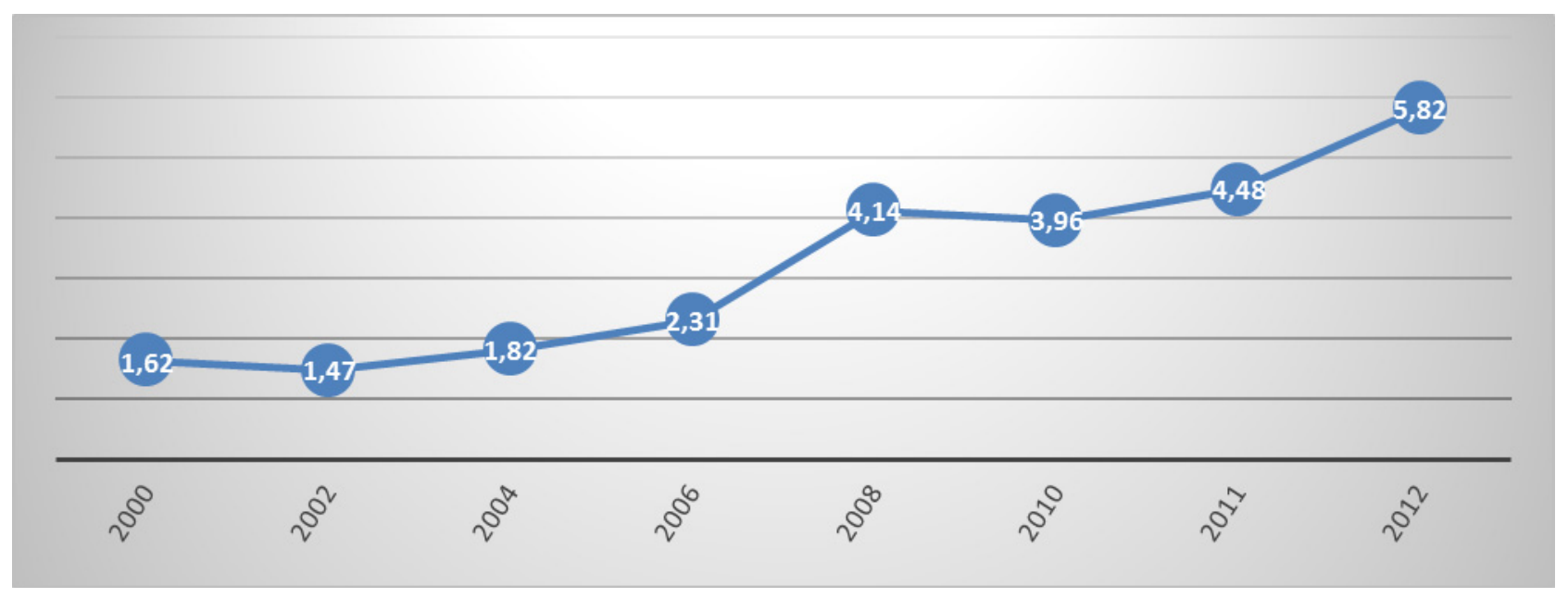

Figure 7. Resulting ratio of young households wealth-Median annual wealth of total Italian households divided by the annual median young households' wealth

Source: Monti, L. (Ed.). (2015).

According to the Survey of Household Income and Wealth by the Bank of Italy in 2012, net total wealth fell $2.9 \%$ in real terms compared with the previous year reaching 143,301 euro as absolute value.

This fall can be attributed in large part to the drop-in value of the real estate. Indeed in 2012, economic difficulties faced by families, especially by the younger ones, worsened (see increasing ratio in Figure 8): the fall in real disposable income and in real net total wealth led to a decrease in consumer spending and an increase in poverty. Over 35 years old households wealth records a more positive long-run trend than young households wealth. Annual wealth of total households grew by almost 30 percent in real terms, between 1991 and 2012, mainly due to the growth of value of the property. According to "Report on Equitable and Sustainable Wellbeing" (BES 2014). Italy continues to have one of the highest net real wealth figures compared with the other European countries, largely a consequence of widespread home ownership. However, the intensity and duration of the economic crisis has both reduced the value of this wealth and also increased economic inequality, poverty and material deprivation.

The median wealth of households whose head aged over 64 increased by about 38 points compared with the overall median. During the same period, younger families showed instead a strong worsening of their relative position and this is not so surprising. The older generation having more stable and often profitable jobs than the younger generation, were able to save their own money and buy, when possible, a house which represented a huge part of their wealth. The worsening is/was determined also by the negative impact of properties depreciation, in some cases leading to a negative net wealth: i.e., the value of the property is less than the nominal residual loan (Willetts, 2010).

Finally, we can observe the following aggregate increase of the Income \& wealth indicators, confirming the negative forecast presented in chapter 2 . 




Figure 8. Income \& wealth ratio variations

Source.: Monti, L. (Ed.). (2015).

\subsection{Housing}

The Housing area refers to Affordability, housing cost and house building. The ratio of housing costs compares the median levels of income among those aged 16-24 to housing price in Italy, as shown in Figure 9.

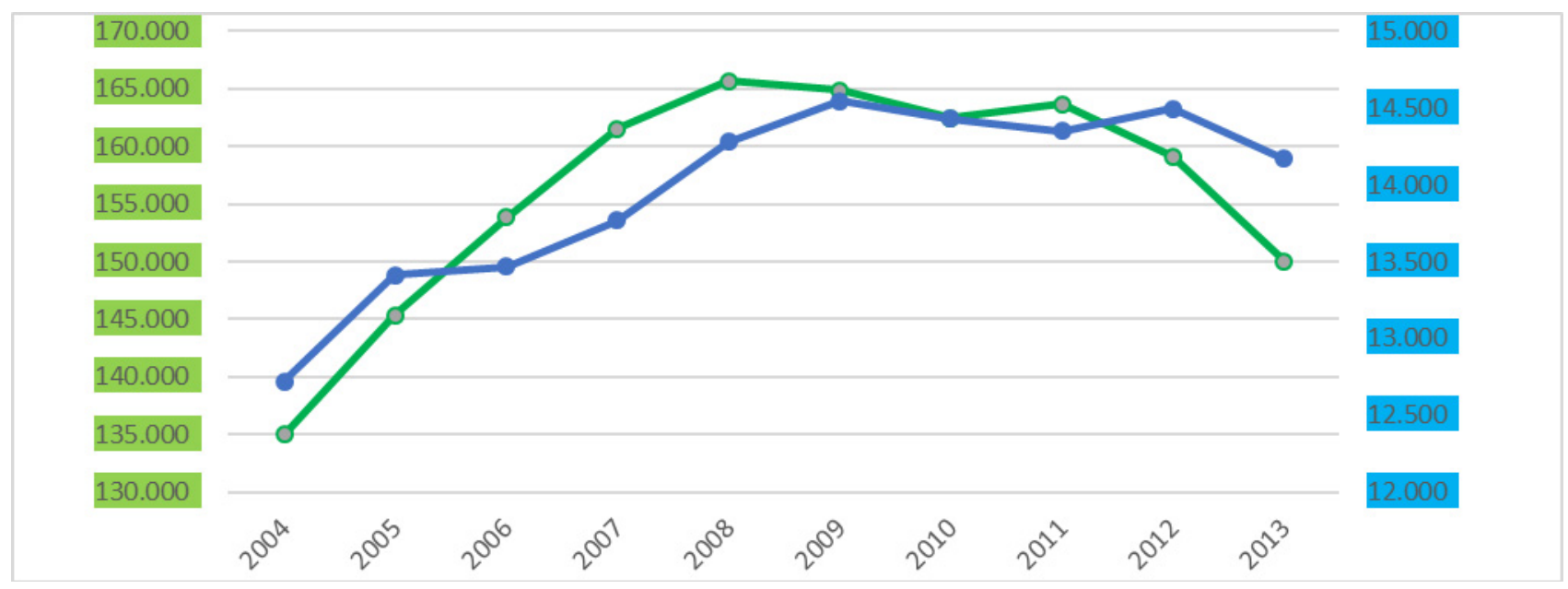

Figure 9. Median annual incomes of those aged 16 to 24 (blue line) compared to median house prices (green line). Euro

Source: Monti, L. (Ed.). (2015). 




Figure 10. Resulting ratio of house price affordability-ratio of median house prices to median annual income of those aged 16-24

Source: Monti, L. (Ed.). (2015).

The housing price strongly depends on housing demand. In fact, the high number of transactions is the main cause of the house price boom. An increase in the total disposable income accounted for the rise in the housing demand (Bank of Italy, 2013). The demand has been fostered by a decline in borrowing rates (Baldini, 2010).

In 2008, the house price reached its historical peak. Since then the ratio of affordability declined as a result of a sharp drop in the housing price. The housing price dropped principally due to a contraction in housing demand during the time of economic crisis. Houses started to be "un-affordable" in comparison to the median income (Bank of Italy, 2009). The financial crisis triggered a process of banks' deleveraging, and as a consequence, the cost of credit increased together with the tightening of the conditions required to obtain a mortgage loan. There has been a reduction in the availability of loans to households. The credit crunch, as shown by indicator 11, was especially strong for young people. The credit crunch significantly affected the reduction in the demand for housing so the price dropped.

The year 2011 represents another turning point because after a small decrease of the housing affordability in 2009 and 2010 it increased again. It is due to the negative trend of young people's disposable income that since 2010 the housing price has started to decrease, as shown in previous paragraphs.

The ratio of housing costs (Figure 12) considers the average housing expenditure as a proportion of the median annual income of young people (Figure 11). The housing costs included expenses for housing; fuel and energy; furnishings, households equipment and services. Once the proportion of income necessary to cover the housing cost is calculated, it is possible to discern how much is left to individuals.

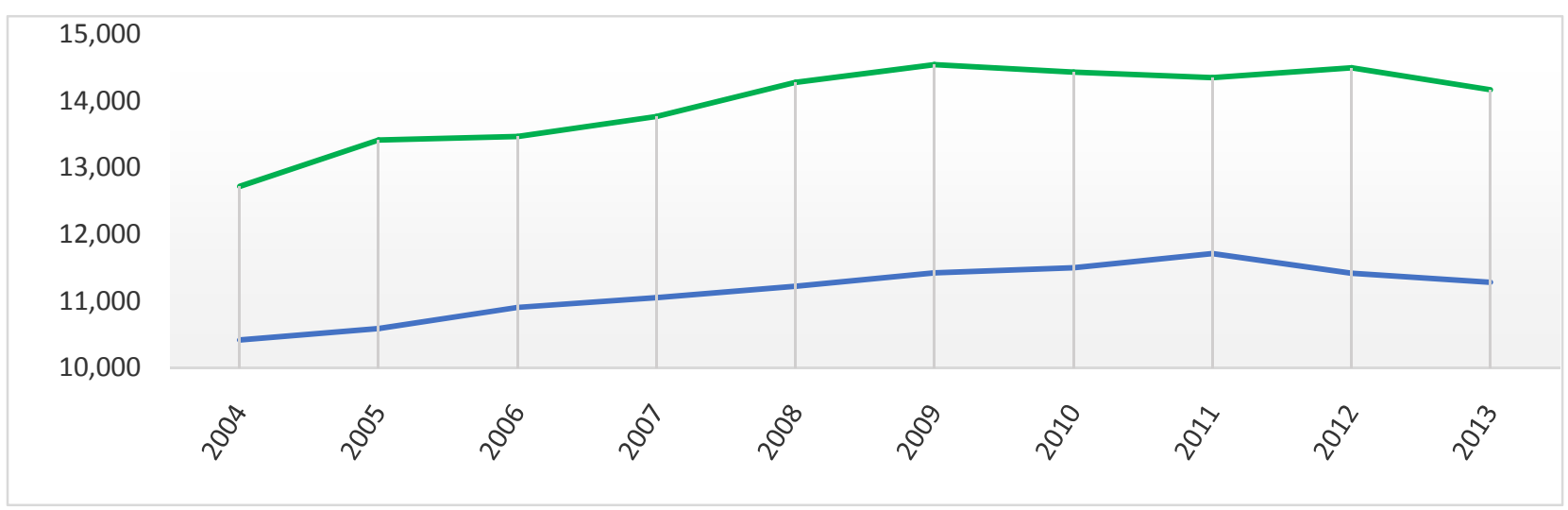

Figure 11. Housing costs (blue line) and disposable income of those aged 16-24 (green line)-Euro 


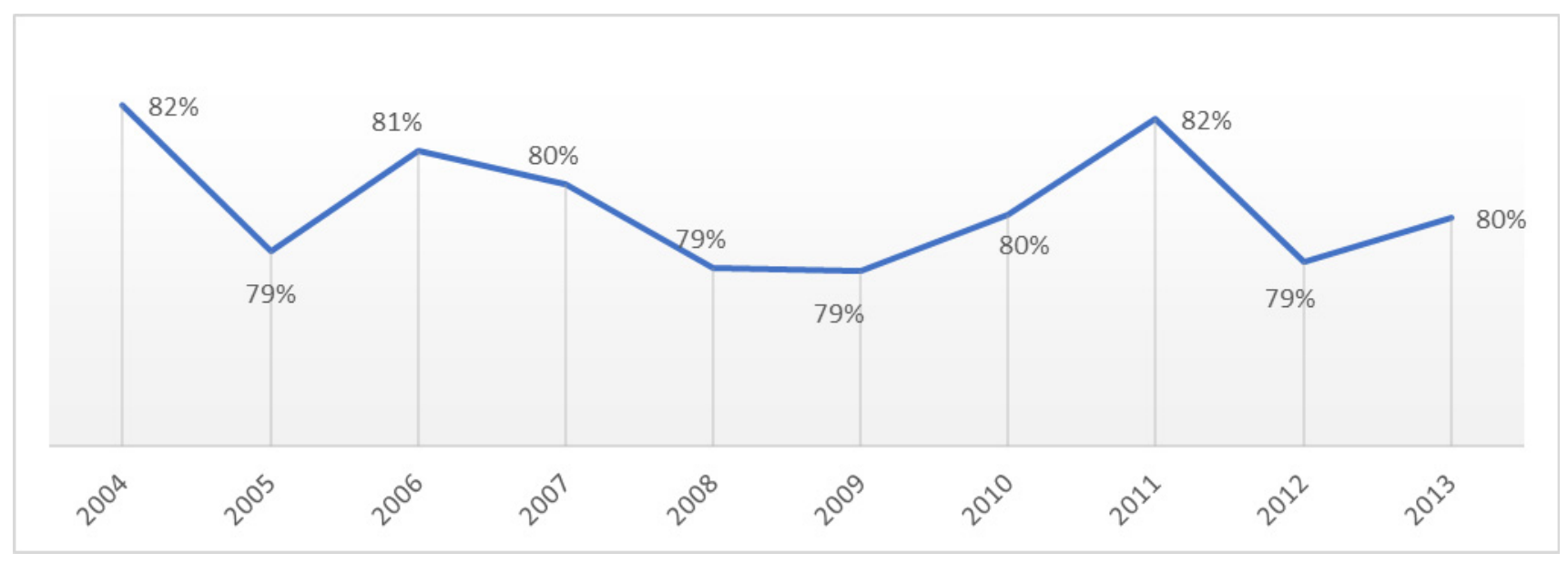

Figure 12. Housing costs as a proportion of disposable income

Source: Monti, L. (Ed.). (2015).

Many authors suggest that there should be a deduction of housing costs from income to calculate the individuals' well-being and their living standards (Raitano, 2013). To measure the disposable income of young people after deducting housing costs is the aim of this indicator.

As shown in Figure 12, from 2004 to 2005 the ratio decreased, but in 2006 it increased, again. A similar increase reflected a growth in housing costs, which in 2006 rose by $3 \%$. In the same year, the component of housing costs that grew the most was the expenditures for fuel and gas, which from 2004 to 2006 grew by $11 \%$. According to the analysis of Federconsumatori in 2006, the bills paid by households in the same year were the most expensive, compared with the 10 previous years (Federconsumatori, 2008). The rising price of oil was identified as the cause.

The strong dependence on energy imports makes Italian bills quite vulnerable to fluctuations of fossil fuel costs such as oil price (Legambiente, 2012). To compound matters, in 2006, the disposable income did not increase, which contributed to the ratio's increase.

In 2007 the ratio decreased reflecting an increase in income. At the same time, the furnishings, households' equipment and service expenses kept falling as in the previous years; and the fuel and energy expenses in 2007 dropped noticeably. Indeed, the periodic update of electricity and gas fees, provided a reduction in electricity and gas costs. The inter-ministerial decree of December 2007 provided a "bonus" for bills (Ministero dello Sviluppo Economico, 2007).

In the following year, the expense for fuel and electricity rose by another $13 \%$, due to the impact of fossil fuels. Despite such a discernible increase in one item of expenditure that composes the total housing costs, in 2008 the ratio results were positive. The ratio improves because the housing costs rate slowed down. Compared to other years, 2009 is identified as the year in which the housing costs impacted less on income. It is marked as a turning point because since then, the ratio started to increase again. In 2011 the ratio reached one of its worse values, with only $18.4 \%$ of income left to expenditure different from housing costs. The increase in the ratio accounts for a drop in the young disposable income starting a new negative trend with 2012 as an exception. This latter year reflects the negative trend registered for the first time in housing costs. There was an increase in fuel and energy expenditure, but for the first time housing expenditure was negative. Due to the low purchasing power of individuals and the high offer of houses for rent, the rental amount decreased further (Tecnocasa, 2013). Indeed, another Tecnocasa's survey shows that $41,9 \%$ of those whom are looking for renting a house are 18-34 years old (Tecnocasa, 2012).

Moreover, the furnishings, households equipment and services' expenditure, that since 2004 had been constantly decreasing, from 2011 to 2012 remarkably contracted by $9 \%$, contributing to the housing costs decrement. The poor quality of furniture which equipped the houses for rent appears to be another element that influenced the decrease in the real amount required by landlord (Tecnocasa, 2013).

The last sub indicator compares the number of building permissions to the number of households. Building permits indicate the evolution in the number of dwellings used for residential purposes (Figure 13). 




Figure 13. Number of building permits in Italy (blue line) as a proportion of the number of households (green line)

Source: Monti, L. (Ed.). (2015).

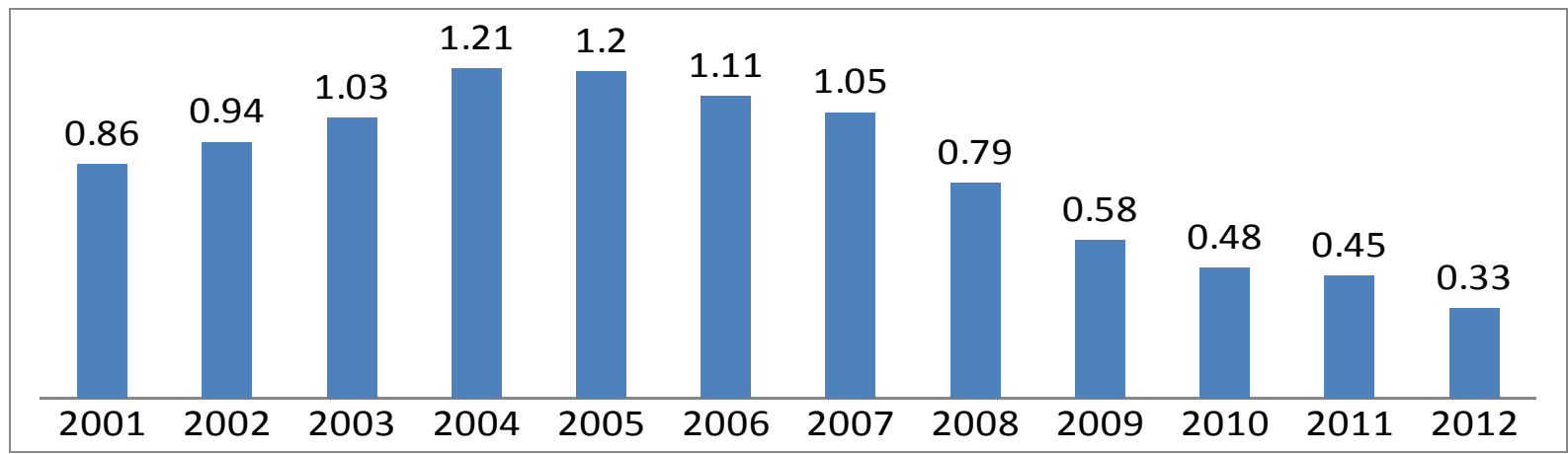

Figure 14. Number of houses built as a proportion of the n. of Households

Source: Monti, L. (Ed.). (2015).

The rate of population growth remained quite stable while the number of building permissions from 2001 to 2004 increased significantly causing an increase in the ratio. The high number of permissions issued in 2004 was the result of a dynamic housing market. In fact, as explained before, since 2000 the housing demand was high and 2004 is marked as a positive milestone also in the housing affordability.

The drop reflects a reduction in the number of building permissions issued. Indeed, in these years the housing demand and the number of transactions began to deteriorate due to an increase in housing price (Bank of Italy, 2009). The reduction in number of building permits reflected also a contraction in 2004 of public investment in the sector due to fiscal consolidation (Banca d'Italia, 2013).

From 2007 to 2008, the house-building rate decreased by 25\% and from 2008 to 2009 by 27\%. This dramatic drop accounted for the high number of unsold homes during the crisis (Finizio, 2014; Banca d'Italia, 2009), that increased the risk of bankruptcy for construction companies (Banca d'Italia, 2013). Consequently, a reduction in house prices further discouraged firms to build new premises (Nobili \& Zollino, 2012).

Moreover, the financial crisis led to a process of banks' deleveraging and a consequent increase in the cost for loans granted to construction firms (Banca d'Italia, 2009). Loans are a crucial ingredient of housing supply, to the extent that investment plans are heavily dependent on bank credit (Nobili \& Zollino, 2012). 
In these last years, the negative trend remains unchanged. In 2012, the building permits were reduced by $27 \%$ signalling another negative milestone. Beyond the economic crisis and its impact on all aspects of the housing market, the drop in the building permits is also due to the number of administrative permits, time and the costs (Finizio, 2014a). According to the report of the World Bank that assesses the ease of doing business, as for construction permits Italy ranked 122 out of 189 countries, with an average of 233 days necessary to obtain a permit (The World Bank Group Corporate Flagship, 2014). Finally, we can register the following aggregate increase of Housing indicators (Figure 15).

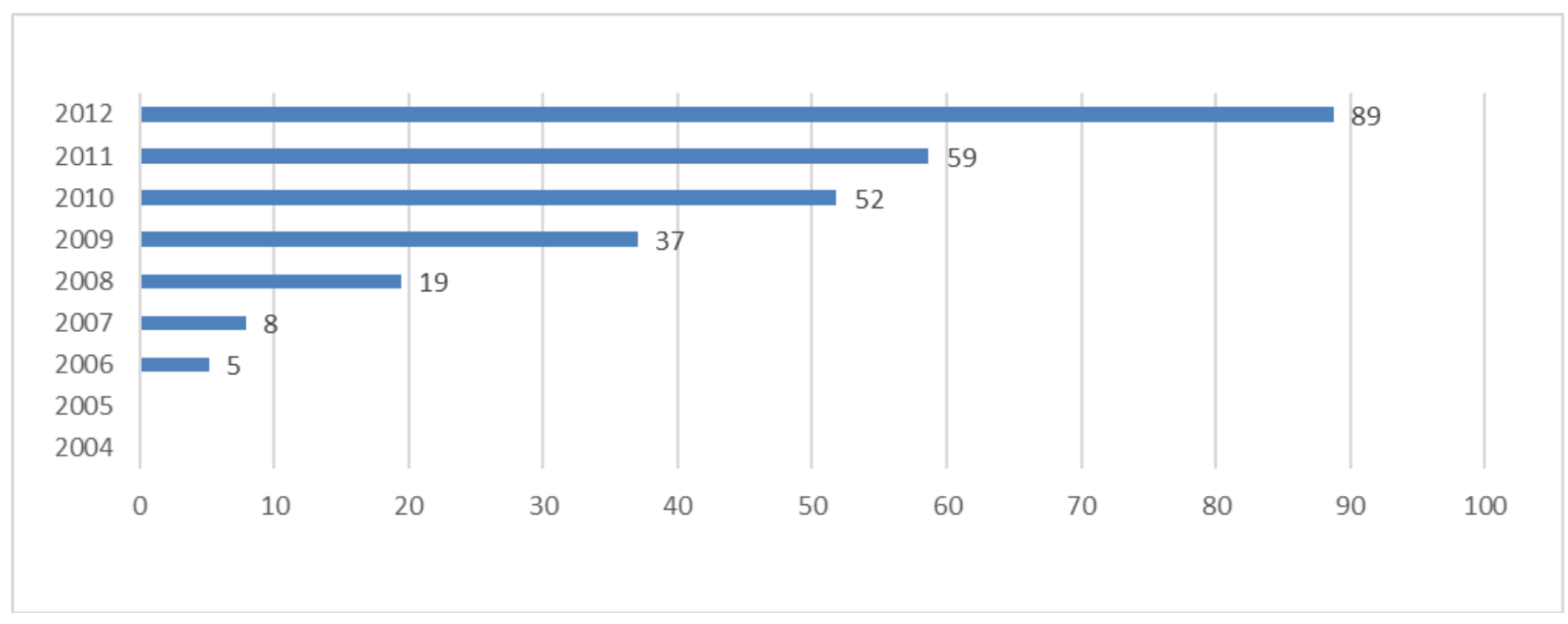

Figure 15. Housing percentage variation

Source: Monti, L. (Ed.). (2015).

\subsection{Pensions}

The area of Pensions data analysis assesses the changing cost of the state pension in relation to the size of the Italian workforce. The reference to the employed is done to link expenses and real direct contribution to the system by employees and companies.

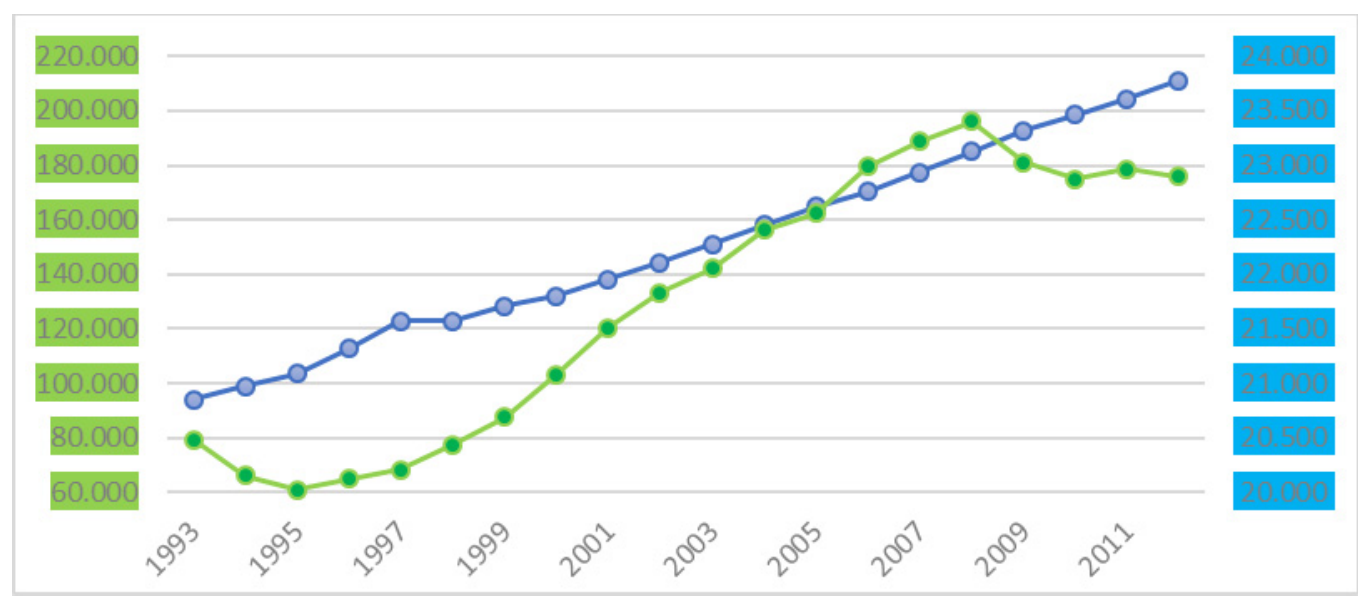

Figure 16. Italian employed workforce (blue line) compared to total cost of state pension (green line-million euro) 
As Figure 16 clearly illustrates, pension costs constantly increased, while from 2009 the workforce started to decrease.

In the first half of the 1990s the cost of pensions per person grew noticeably. Due to the economic recession in 1992 and 1993, the workforce decreased, and this caused an increase in the ratio because the workforce bearing the pension cost decreased as well. The increase for pensions expenditure was extremely high until 1997. In order to contain the trend a number of reforms were adopted and as a result, the pensions were now linked to the effective contribution paid by workers (Williamson, 2004).

The new system established the equivalence between the contributions paid and the benefits received. However, the new pension scheme was implemented gradually depending on the years of service accumulated since 1995 (Sartor, 2001). This increases the intergenerational inequity and assures wealth transfer in favour of the generation that could still benefit from the previous system.

Due to this very long transitional period, the implementation of the reform was, and still is, extremely gradual (Brugiavini \& Peracchi, 2007). Beyond the rules for benefit computation, the reforms tackled with indexation rules, retirement age and eligibility criteria.

The law no. 449/1997, undertaken by the government of the Prime Minister Prodi, tried to accelerate the measures and targets implemented by reforms from 1992 till 1995 (Mayr, 2013). The only year in which the cost per person slightly reduced was 1998, in fact it passed from 5.895 euro per capita in 1997 to 5.835 euro per capita in 1998.

At the beginning of 2000, the ratio representing pension costs per person kept increasing but at lower rate when compared to the 1990s. This accounts for an improvement in the numbers of the workforce, yet it is important to underline that pension costs were growing at lower rates. The number and the value of pensions emitted decreased (Itinerari Previdenziali, 2014). The number of beneficiaries went down thanks to the increase both in age and in the number of years' service required to retire. As a matter of fact in 2011 the expenditure for pensions grew at a lower rate.

Finally the Law no. 214/2011 (so called Fornero Reform), further increased the required age for old age pensions. The age increased from 65 to 66 for all workers (from 60 to 62 for women working in the private sector) and the aim was to align the retirement age of women to those of men in 2018. Moreover, the minimum number of contributory years, necessary to be entitled to old age pension, increased from 5 to 20 (Jessoula, 2013).

Seniority pensions, allowing retirement prior to reaching pensionable age, were abolished. The possibility of early retirement is possible only under specific rules. Moreover, in order to contain pensions' expenditure the reform suspended indexation of pensions above 1,400 Euros/month gross in 2012-2013.

If the expenditure trend was constantly raising up, the number of workers stopped increasing at the beginning of the crisis, as clearly shown in Figure 17. The pro capita costs consequently worsened in the period 2007-2012 from 7,415 to 9,416 (Figure 17). 


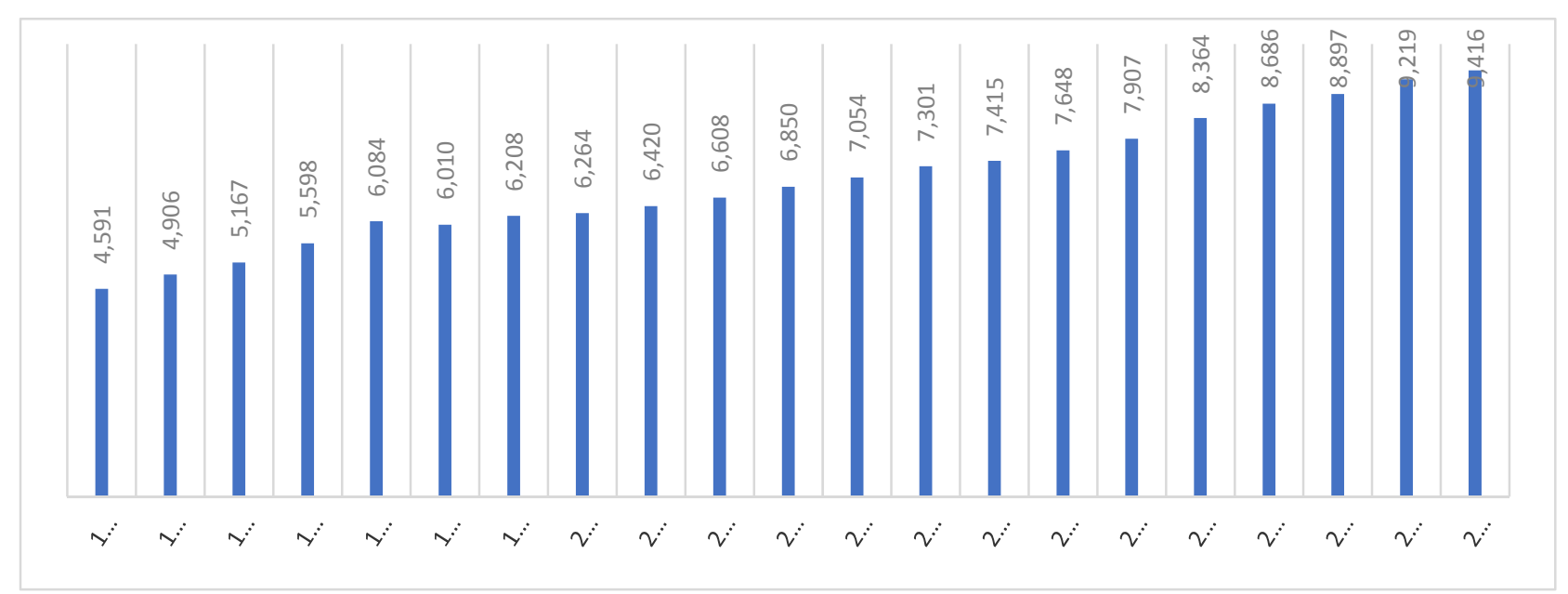

Figure 17. State pension costs per working person (in euro)

Source: Monti, L. (Ed.). (2015).

Considering the unfunded pensions cost, Figure 18 clearly indicates that the deficit rose sharply until 1995 . The generosity of the public pension in those years was due to the possibility of early retirement, and the use of anticipated pensions as a social safety net (Sartor, 2001). Simultaneously, the recession in the years 1992-1993 contracted the numbers of the work force, and the ratio reached its highest value in 1995.



Figure 18. Cost of unfunded liabilities (blue line) of Italian Public Sector Pensions (million) vs thousands workforce (green line)

Source: Monti, L. (Ed.). (2015). 


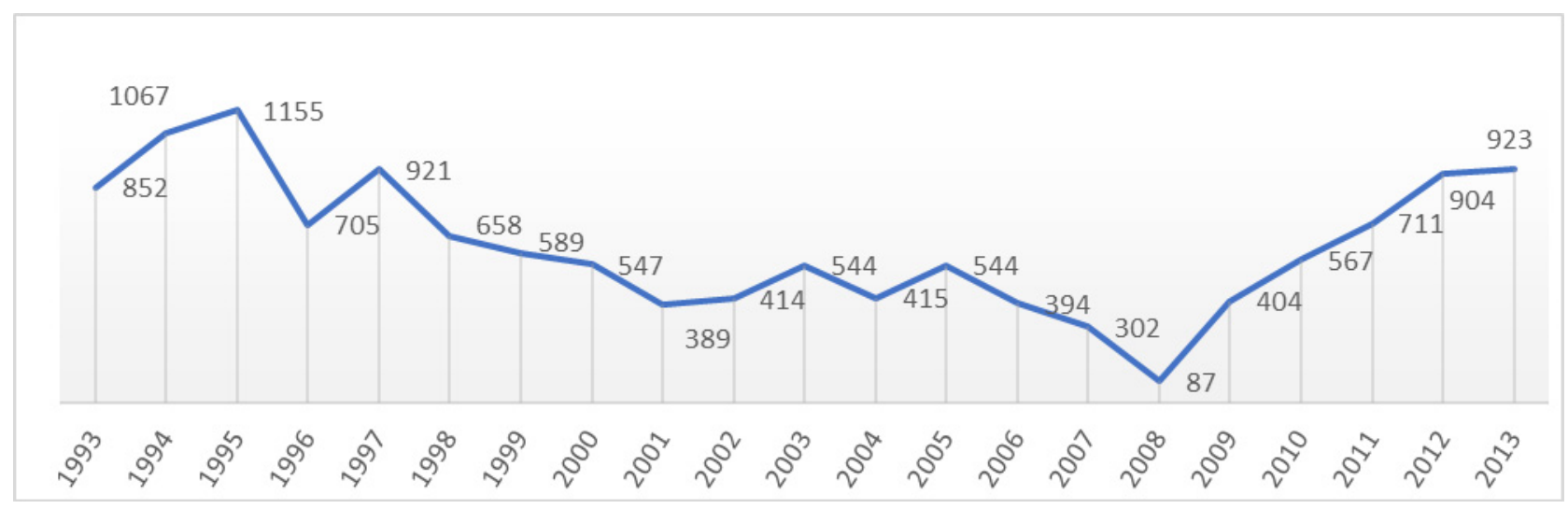

Figure 19. Resulting liability for unfunded liabilities of Italian Public Sector Pension Costs per capita in the workforce (euro/person)

Source: Monti, L. (Ed.). (2015).

The year 1996 is marked as the turning point because since then the unfunded pension liability per person in the work force started to decrease. It accounts for a reduction in the pension expenditure due to the strong decrease in the number of pensions granted and for the variation of their amount. Yet, in the following years, an increase in the contributions is registered. It is due to both an increase in the employment rate since 1996 and an increase in the rate of taxation, as established by the above mentioned reforms. Additionally, a switch from wage to price indexation for pensions was established.

At the beginning of the millennium, pro capita costs start to rise again. The progressively aging population is one of the main reasons why current pension system is no longer sustainable (European Commission, 2012).

The number of retirements for baby boomers is increasing while the working population begins to decrease. This process largely contributes to the disequilibrium between contribution and benefits.

The increasing rate of employment and cuts in the number of pensions, leads to a consistent reduction the gap between contributions and benefits (Itinerari Previdenziali, 2014). Indeed, in 2008 the unfunded pensions liability per person in the workforce arrived at 87 euro per person (Figure 20).

After 2009, which represented a real turning point, the ratio started rising dramatically. Due to the effect of the crisis, the gap between contributes and benefits widened significantly. As a consequence of the sovereign debt crisis since the mid-2010, all reforms adopted after 2008 aimed at dealing with public pension expenditure (Jessoula, 2013). The reforms, part of the austerity package, were aimed at further reducing the expenditure in the short-medium term, and to shorten the transition period to the rules introduced in the $90 \mathrm{~s}$. Moreover, because of these austerity policies, taxes increased. However, the economic and financial crisis of 2008, strongly affected the rate of employment, and despite the increase in tax contributions, the unfunded liability increased dramatically. As a result, in 2013 the unfunded pension liability reached 904 euro per person in the workforce, close to the 1994 peak.

Finally, there are the variations of the Pension aggregate indicator, confirming the deterioration over the last period. 


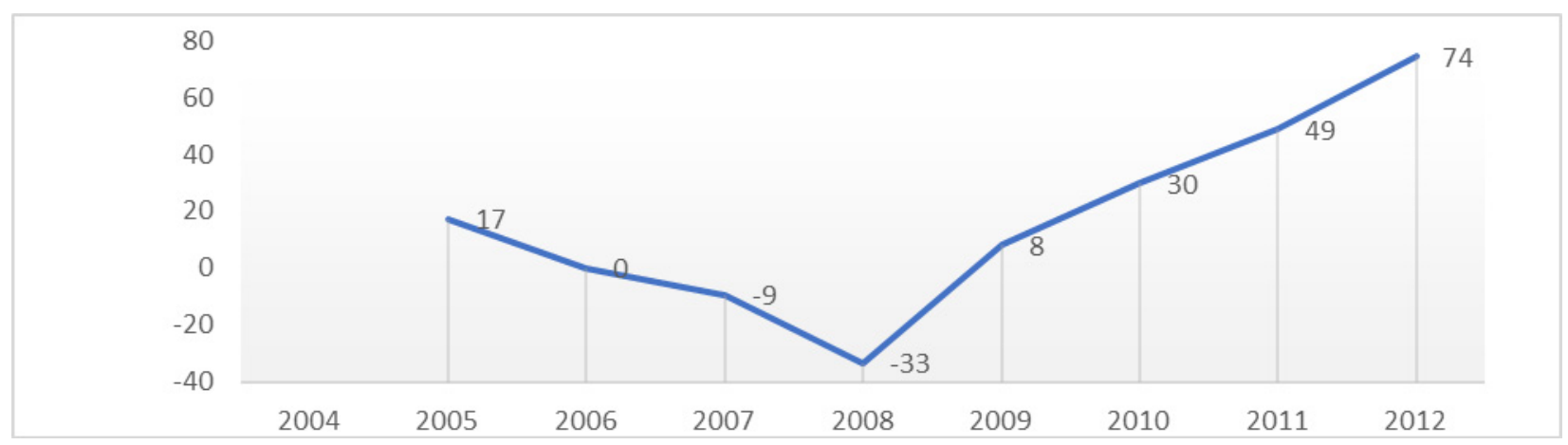

Figure 20. Variations of the aggregate indicator of Pensions

Source: Monti, L. (Ed.). (2015).

\subsection{Final Remarks}

The results of this pilot application of GDI are that there is a certain relation between some of these milestones and negative trends or, in some cases, the total irrelevancy of macroeconomic policies adopted by the government of the selected country such as labour reform and pension reform.

Data analysis of the three major causes for the worsening of GDI allow me to say that any soft and occasional reforms do not help in solving the worsening of generational divide and that every new action to fight youth discrimination must consider a realistic timing and a multidimensional and integrated approach.

Another conclusion is that a specific and targeted intervention on youth unemployment, following the European model of Youth Guarantee, risks having a minor impact on the generational divide if not integrated within a favourable macroeconomic trend or within a whole intergenerational sustainable policy.

In other words, the GDI test on the selected country clearly demonstrates that a standing alone labour reform or a single incentive for a start-ups and entrepreneurship, will not be the milestone able to stop the worsening of generational divide and stop the youth discrimination in labour market, in the credit market and housing.

The suggestion is therefore to introduce a model of policy evaluation, such as the proposed GDI index, which is able to define the generational impact on young generation, remove the negative generational impact of certain politics, promote and monitor a sound youth strategy, to help prevent new future breaks of the intergenerational contract.

\section{Acknowledgements}

This article takes into account the activity of ClubdiLatina research team during the period October 2014-April 2015 involving Zelda Azzarà, Francesca Berti and Piera Matarazzo, and the Fondazione Bruno Visentini research team during 2016, involving Roberto Cerroni and Silvia Di Gaspare. The proof reading has been provided by Jan Kermer. Contribution to the publication expenses has been provided by Fondazione Bruno Visentini.

\section{References}

Auerbach, A. J., Gokhale, J., \& Kotlikoff, L. J. (1991). Generational Accounts-A Meaningful Alternative to Deficit Accounting. In National Bureau of Economic Research Working Paper (No. 3589). Cambridge, MA. https://doi.org/10.1086/tpe.5.20061801

Auerbach, A. J., Gokhale, J., \& Kotlikoff, L. J. (1995). Restoring Generational Balance in U.S. Fiscal Policy: What Will It Take? In Economic Review. Cleveland: Federal Reserve Bank of Cleveland.

Baldini, M. (2010). La casa degli Italiani. Bologna, IT: Il Mulino.

Banca d'Italia. (2009). L'andamento del mercato immobiliare italiano e i riflessi sul sistema finanziario. In Occasional Papers (No. 59). Rome, IT: Banca d'Italia.

Banca d'Italia. (2013). Le tendenze del mercato immobiliare: l'Italia e il confronto internazionale. In Workshop and Conferences (No. 15). Rome, IT: Banca d'Italia.
Bankpedia.
(2015).
Credit
crunch.
Retrieved
from http://www.bankpedia.org/index.php/en/89-english/c/23882-credit-crunch 
Beaudry, P., \& Green, D. A. (2000). Cohort Patterns in Canadian Earnings: Assessing the Role of Skill Premia in Inequality Trends. In The Canadian Journal of Economics (No. 33, pp. 907-936). https://doi.org/10.1111/0008-4085.00047

Brugiavini, A., \& Peracchi, F. (2007). Fiscal Implications of Pension Reform in Italy. In Social Security Programs and Retirement around the World: Fiscal Implications of Reform. Chicago: University of Chicago Press.

Calabrese, T. (2009). Public Pensions, Public Budgets, and the Risks of Pension Obligation Bonds. In Society of Actuaries Public Pension Finance Symposium May 2009.

Cavalli, A. (2002). Giovani del nuovo secolo. Quinto rapporto IARD sulla condizione giovanile in Italia. Bologna, IT: Il Mulino.

Cnel, Commissione speciale dell'Informazione. (2013). Rapporto sul mercato del lavoro 2012-2013. Rome, IT: Cnel.

Commonwealth Government. (2002). Intergenerational Report.

European Commission. (2012, February 16). White Paper: An Agenda for Adequate, Safe and Sustainable Pensions, COM (2012) 55 final. Brussels: European Commission.

Eurostat. (2013). European system of accounts ESA 2010. Luxembourg: Publications Office of the European Union.

Federconsumatori. (2008). VII Indagine Nazionale Energia sulle bollette elettriche.

Finizio, M. (2014a, September 29). Edilizia, permessi per nuovi cantieri in calo del 70\%. In Il Sole 24 Ore.

Finizio, M. (2014b, October 8). In Italia ci sono 540mila case invendute, 16 su mille. Record a La Spezia e Trieste. In Il Sole 24 Ore.

Fitoussi, J. P. (2013). Le Théorème du lampadaire. Paris, FR: Les liens qui libèrent.

Freeman, R. (1979). The Effect of Demographic Factors in Age-Earnings Profiles. The Journal of Human Resources, 14, 289-318. https://doi.org/10.2307/145573

Frischmann, B. M. (2005). Some Thoughts on Shortsightedness and Intergenerational Equity. Law Journal, 36, 457.

Gale, W. G., \& Slemrod, J. B. (2001). Rethinking the Estate and gift Tax. An Overview. In W. G. Gale, J. R. Hines, \& J. Slemrod (Eds.), Rethinking Estate and Gift Taxation. Washington: Brookings Institution Press. https://doi.org/10.3386/w8205

Gallo, A. (2012). Guardo al futuro. I giovani tra partecipazione politica e governo locale. In Indagine Cittalia. Fondazione Anci Ricerche.

Gorlich, D., Stepanok, I., \& Al-Hussami, F. (2013). Youth Unemployment in Europe and the World: Cause, Consequences and Solutions. Kiel Policy Brief, 59.

Gosling, A., Machin, S., \& Meghir, C. (2000). The Changing Distribution of Male Wages in the UK. The Review of Economic Studies, 67, 635-666. https://doi.org/10.1111/1467-937X.00148

Gruppo Mutui Online. (2015). Gruppo Mutui Online. Retrieved from http://www.gruppomol.it/index_eng.asp

Hennessy, D. A. (2008). The impact of commuter stress on workplace aggression. Journal of Applied Social Psychology, 38(9), 2315-2335. https://doi.org/10.1111/j.1559-1816.2008.00393.x

Itinerari Previdenziali. (2014). Rapporto n. 1, anno 2014. Il bilancio del sistema previdenziale italiano. Milan, IT: Collana Itinerari Previdenziali.

Jappelli, T., Padula, M., \& Pica, G. (2011). Do transfer Taxes Reduce Intergenerational Transfers? In CSEF Working Paper (No. 242).

Jessoula, M. (2013). Italy: Social partners involvement in the reforms of pension system. European Observatory of Working Life.

Kluger, A. N. (1998). Commute variability and strain. Journal of Organizational Behavior, 19(2), 147-165. https://doi.org/10.1002/(SICI)1099-1379(199803)19:2<147::AID-JOB830>3.0.CO;2-Y

Koslowsky, M., Avraham, N. K., \& Reich, M. (1995). Commuter Stress, Causes, Effects and Methods of Coping. In Springer Science \& Business Media. The Plenum Series on Stress and Coping. 
Kuennen, K. (2012). The impact of long commuting on the working individual. Business Studies Journal, Supplement 1, 4.

Laslett, P. (1992). Is There a Generational Contract? In P. Laslett, \& J. Fishkin (Eds.), Justice Between Age Groups and Generation (pp. 25-47). New Haven: Yale University Press.

Leach, J., \& Hanton, A. (2013). Where Do Young People Do Worst? In How Intergenerational Fairness differs across the 12 regions of the United Kingdom. IF Report 2013. London, UK: The Intergenerational Foundation.

Leach, J., \& Hanton, A. (2014). The IF Intergenerational Fairness Index: 2014 Edition. London, UK: The Intergenerational Foundation.

Leach, J., \& Hanton, A. (2015). The IF Intergenerational Fairness Index: 2015 Edition. A 10\% decline since 2010. London, UK: The Intergenerational Foundation.

Leach, J., Broeks, M., Ostensvik, K., \& Kingman, D. (2016). European Intergenerational Fairness Index: A crisis for the young. London, UK: Intergenerational Foundation.

Legambiente. (2012). La verità sulle bollette elettriche. Dossier. Legambiente.

Lyons, G., \& Chatterjee, K. (2007). A human perspective on the daily commute: Costs, benefits, and trade-offs. Transport Reviews, 28(2), 181-198. https://doi.org/10.1080/01441640701559484

Marchetti, F., \& Monti, L. (Eds.). (2017). Il divario generazionale tra conflitti e solidarietà. Report 2017. Viterbo, IT: Dialoghi.

Mayr, Z. (2013). The Italian pension system: Reforms and the change in the future composition of pension income. In Aarhus School of Business and Social Sciences (MSc Finance Thesis).

Ministero dello Sviluppo Economico. (2007). Decreto del 28.12.2007.

Monti, L. (2016). Ladri di futuro. La rivolta dei giovani contro l'economia ingiusta. Rome, IT: Luiss University Press.

Monti, L. (Ed.). (2015). Divario Generazionale. Il senso della dismisura. Ricerche del Comitato Scientifico della Fondazione Bruno Visentini, Viterbo, IT: Alter Ego.

Monti, L., Pepe, E., \& Rizzuti, G. (2015, December). E-government and Open Data Boosting Economic Growth: A New Index. Journal of Business and Economics, $6(12)$. https://doi.org/10.15341/jbe(2155-7950)/12.06.2015/009

Nobili, A., \& Zollino, F. (2012). A Structural Model for the Housing and Credit Markets in Italy.

Oecd. (2014). Household debt. Retrieved from http://data.oecd.org/hha/household-debt.htm

Osberg, L. (1997). Meaning and Measurement in Intergenerational Equity.

Pizzuti, F. R. (2013). Rapporto sullo stato sociale. Naples, IT: Edizioni Simone.

Raitano, M. (2013). L'impatto delle spese per l'abitazione di residenza sulla distribuzione dei redditi familiari in Italia. In Paper presented at the Workshop "Housing, Disuguaglianza e Welfare”. Rome, IT: University La Sapienza.

Rawls, J. (1971). A Theory of Justice.

Roosevelt Institute Campus Network. (2011). Budget for a Millennial America. A Federal Budget Plan that Reflects the Millennial Generation's Priorities. A Think 2040 Initiative.

Rosolia, A., \& Torrini, R. (2007). The generation gap: Relative earnings of young and old workers in Italy. In Bank of Italy Working Papers (No. 639). Rome, IT: Banca d'Italia.

Salvini, S., \& Ferro, I. (2005). Un difficile equilibrio: I giovani tra flessibilità del mercato del lavoro e scelte familiari. Conference "Famiglie, nascite a politiche sociali", Florence, IT: Dipartimento di Statistica "G. Parenti", Università di Firenze.

Sartor, N. (2001). The long-run effects of the Italian Pension Reform. International Tax and Public Finance, 8(1), 83-111. https://doi.org/10.1023/A:1008745617309

Sikora, R. I., \& Barry, B. M. (1978). Obligations to Future Generations. Philadelphia: Temple University Press.

Tecnocasa. (2008). Casa Trend. Analisi del mercato immobiliare e creditizio.

Tecnocasa. (2012). Analisi socio demografica: Acquirenti e Venditori II semestre 2012. 
Tecnocasa. (2013). Casa Trend. Analisi del mercato immobiliare e creditizio italiano.

The Commonwealth. (2013). Youth Development Index Results Report.

The World Bank Group Corporate Flagship. (2014). Doing Business 2014 (11th ed.).

Tremmel, J., Mason, A., Godli, P. H., \& Dimitrijoski, I. (2015). Youth Quotas and other Efficient Forms of Youth Participation in Ageing Societies.

Turcotte, M. (2008). Like commuting? Workers' perceptions of their daily commute. Canadian Social Trends. Statistics Canada, 11(8).

Unicef. (2013). Child Well-being in Rich Countries: A comparative overview. In Innocenti Report Card 11. Florence, IT: Unicef Office of Research. https://doi.org/10.18356/0aea8e54-en

Vanhuysse, P. (2013). Intergenerational Justice in Aging Societies: A Cross-national Comparison of 29 OECD Countries. Gutersloh, DE: Bertelsmann Stiftung.

Vanhuysse, P. (2014). Intergenerational Justice and Public Policy in Europe. In OSE Opinion Paper (No. 16).

Willetts, D. (2010). The pinch. London, UK: Atlantic Books.

Williamson, J. (2004). Assessing the National Defined Contribution Model. In Issue in Brief (No. 24).

\section{Copyrights}

Copyright for this article is retained by the author(s), with first publication rights granted to the journal.

This is an open-access article distributed under the terms and conditions of the Creative Commons Attribution license (http://creativecommons.org/licenses/by/4.0/). 